\title{
Intact forests of the Hkakabo Razi Landscape are a hotspot of bat diversity in South-east Asia
}

\author{
Paul J. J. Bates, Pipat Soisook, Sai Sein Lin Oo, Marcela Suarez-Rubio \\ Awatsaya Pimsai, Ariya Dejtaradol and Swen C. Renner
}

\begin{abstract}
The Hkakabo Razi Landscape, in northern Kachin, Myanmar, is one of the largest remaining tracts of intact forest in South-east Asia. In 2016, we undertook a survey in its southern margins to assess bat diversity, distribution and ecology and evaluate the importance of the area for global bat conservation. Two collecting trips had taken place in the area in 1931 and 1933, with four bat species reported. We recorded 35 species, 18 of which are new for Kachin. One species, Murina hkakaboraziensis, was new to science and three, Megaerops niphanae, Phoniscus jagorii, Murina pluvialis, were new records for Myanmar. Our findings indicate high bat diversity in Hkakabo Razi; although it comprises only $1.7 \%$ of Myanmar's land area, it is home to $33.6 \%$ of its known bat species. This emphasizes Hkakabo Razi's importance for conserving increasingly threatened, forestinterior bats, especially in the families Kerivoulinae and Murininae. There is also a high diversity of other mammals and birds within the Hkakabo Razi Landscape, which supports its nomination as a World Heritage Site.
\end{abstract}

Keywords Bats, biodiversity assessments, Chiroptera, Hkakabo Razi Landscape, Kachin, Myanmar, Northern Mountain Forest Complex

Supplementary material for this article is available at doi.org/10.1017/So030605320000630

\section{Introduction}

7 ropical forests in South-east Asia have high levels of 1 species richness and endemism (Kingston, 2010), with four of the world's 25 biodiversity hotspots found in

PAUL J. J. BATES* (ㅇ) orcid.org/0000-0003-3630-739X) Harrison Institute, Sevenoaks, UK

Pipat Soisook (@) orcid.org/0000-0002-1404-3568) and Awatsaya Pimsal (ㄷ) orcid.org/0000-0003-3974-7059) Faculty of Science, Prince of Songkla University, Hat Yai, Thailand

SAI SeIN Lin Oo (잉 orcid.org/0000-0001-9897-6164) Department of Zoology, Mandalay University, Mandalay, Myanmar

Marcela SuARez-Rubio (이 orcid.org/0000-0002-0596-2626) Institute of Zoology, University of Natural Resources and Life Sciences, Vienna, Austria

Swen C. RenNer (Corresponding author, (1) orcid.org/0000-0002-6893-4219) and Ariya Dejtaradol (10 orcid.org/0000-0002-3258-1618) Ornithology, Natural History Museum Vienna, Vienna, Austria. E-mail swen.renner@nhm-wien.ac.at

${ }^{*}$ Also at: University of Natural Resources and Life Sciences, Vienna, Austria

Received 25 February 2020. Revision requested 7 April 2020.

Accepted 1 July 2020. First published online 28 April 2021. the region (Myers et al., 2000). However, South-east Asia, including parts of Myanmar, also has one of the highest rates of deforestation, habitat destruction and degradation (Keenan et al., 2015; Curtis et al., 2018; Estoque et al., 2019). Approximately 80 million ha of forest were lost during 2005-2015, including nearly 4 million ha in Myanmar (Estoque et al., 2019). In the Philippines and parts of Indonesia, it is projected that $98 \%$ of forests will be lost by 2022 (Hughes, 2017). In Viet Nam, forests are becoming more fragmented and degraded, and closed-canopy forests constitute only $4.6 \%$ of the total forested area (WorldBank, 2005). Rapid land-use changes mean that much of the region's fauna is threatened (Kingston, 2010) and the density of threatened vertebrates is amongst the highest in the world (Hughes, 2017). It has been estimated that the region, which includes 20 hotspots of extinction risk (Cardillo et al., 2006), could lose up to $42 \%$ of its biodiversity by 2100 (Sodhi et al., 2004).

With an area of $11,280 \mathrm{~km}^{2}$ (Suarez-Rubio et al., 2020), the Hkakabo Razi Landscape is one of the largest remaining tracts of mainly intact forest in South-east Asia (Bhagwat et al., 2017). It is located along the south-eastern slopes of the eastern sub-Himalayan mountain range and comprises Hkakabo Razi National Park, the Hponkan Razi Wildlife Sanctuary and the proposed southern extension of Hkakabo Razi National Park (Fig. 1; Suarez-Rubio et al., 2020).

The forests of Hkakabo Razi have high structural integrity and experienced low rates of deforestation during 1989-2016 (Suarez-Rubio et al., 2020). During 1991-1999, the annual deforestation rate was $<0.2 \%$, concentrated on the plains of Putao and Naung Mung (Renner et al., 2007). The forests are situated at the meeting point of three biodiversity hotspots: Indo-Burma, Himalaya and Mountains of South-west China (Myers et al., 2000). Bird species richness is high (Renner \& Rappole, 2011; Renner et al., 2015), with $40 \%$ of Myanmar's c. 1,100 bird species occurring in the area (Renner et al., 2015). In 2014, the Hkakabo Razi Landscape was proposed as a World Heritage Site under criteria (ix) and (x) for its high integrity and outstanding ecological values (World Heritage Centre, 2014).

Although the diversity of birds and larger mammals in the Hkakabo Razi Landscape is relatively well known (Rao et al., 2013; Renner et al., 2015), this is not the case for most other taxa. Only two previous surveys included bats: by the Earl of Cranbrook and Kingdon-Ward in 1931 and by Kaulback in 1933. Seventeen specimens of four species were collected during these surveys (Hill, 1962). Elsewhere in 


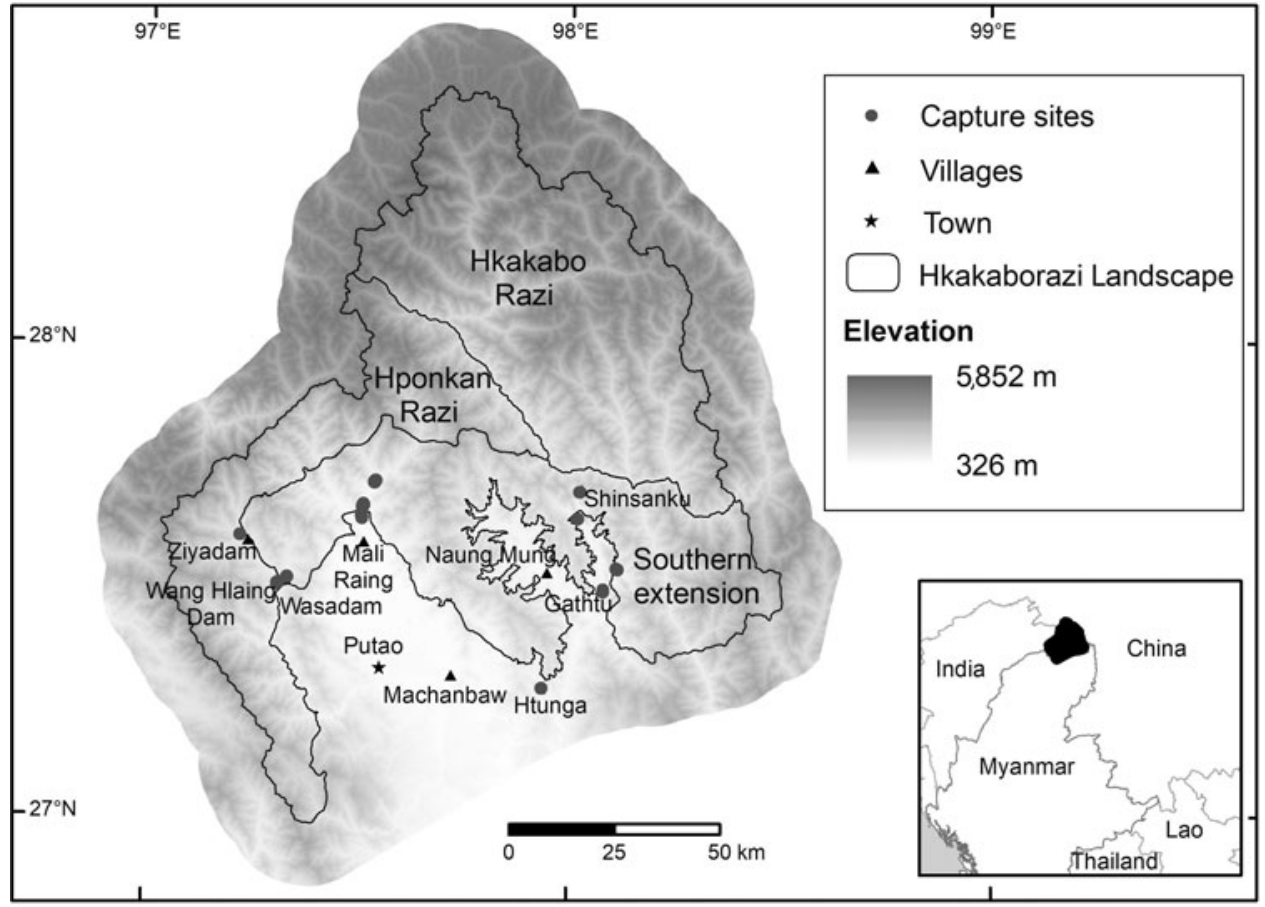

FIg. 1 The Hkakabo Razi Landscape in northern Myanmar, including the 11 capture sites of 2016.
Kachin State bat research was mostly conducted during 19311945 (Bates et al., 2000) and in the early 21st century (Bates et al., 2004; Struebig et al., 2005). None was extensive and only one involved harp-traps and mist-nets (Struebig et al., 2005).

Bats are recognized as a critical component of South-east Asia's fauna, comprising $30 \%$ of the region's mammal species and $50 \%$ of the mammal species within the tropical rainforest ecoregions (Kingston, 2010). South-east Asia is home to $27 \%$ of global bat diversity ( 385 of the currently recognized 1,411 bat species; Simmons \& Cirranello, 2020). Nearly half of the region's bat species are predicted to be extinct by the end of the 21st century, and forestdependent species are particularly vulnerable (Kingston, 2010, 2013; Frick et al., 2019). As Kingston (2010) noted, this is a catastrophic decline, including the loss of the many ecosystem services that bats provide.

\section{Study area}

The mountain ranges of the Hkakabo Razi Landscape encircle the Putao Plains, except to the south, where lowlands give way to the headwaters of the Ayeyarwady River (Fig. 1). The altitude ranges from $450 \mathrm{~m}$ in the Putao Plains to 5,881 $\mathrm{m}$ at the summit of Mount Hkakabo Razi. Except for dry deserts, all major vegetation types are present. The area is predominantly covered by different forest types, tropical to subtropical (semi-deciduous) from lowlands to alpine zones. Above the alpine vegetation, rock/boulder and glaciers/snow fields occur (Renner et al., 2015). Settlements and agriculture are restricted mainly to the flood plains of Putao and Naung Mung (Renner et al., 2007). In some areas, swidden cultivation has created a patchwork of secondary forest in various stages of regeneration. The Hkakabo Razi Landscape is home to $>8$,ooo people, and except for Putao and Naung Mung townships, virtually no other settlement exceeds 100 inhabitants (Suarez-Rubio et al., 2020).

\section{Methods}

We undertook fieldwork during 28 nights at 11 sites (Table 1), in the southern margins of the Hkakabo Razi Landscape at altitudes of 450-1,220 m (Fig. 1), using fourbank harp-traps and mist-nets, and conducting roost surveys and acoustic surveys (Supplementary Table 1). Wherever possible, we used a suite of three capturing methods to maximize success. Four-bank harp-traps were set in forests, across trails and over streams, and checked during 18.00-21.00 and again at dawn. This resulted in a total of 66 harp-trap nights, with one trap-night defined as one trap set per night. Mist-nets (7o denier nylon, $30 \times 30 \mathrm{~mm}$ mesh size; Ecotone, Gdynia, Poland) were also set along and across forest trails and across streams. They were opened during 18.00-21.0o and checked regularly. In addition, we employed some canopy nets; in Tana cave we used mist-nets and hand nets. Mist-net hours, including canopy nets, totalled 718 . We conducted transect and point acoustic surveys with a Pettersson D1ooox bat detector (Pettersson Elektronik, Uppsala, Sweden) and analysed echolocation calls with BatSoundPro4.1 (Pettersson Elektronik, Uppsala, Sweden). We identified bat calls to species level using the call database of the Princess Maha Chakri Sirindhorn Natural History Museum (P. Soisook, 
TABLE 1 Sampling effort by method at 11 capture sites in the Hkakabo Razi Landscape in 2016.

\begin{tabular}{|c|c|c|c|c|c|c|c|c|c|}
\hline Site & Elevation (m) & $\begin{array}{l}\text { House- } \\
\text { holds }^{1}\end{array}$ & Dates & $\begin{array}{l}\text { Harp-trap } \\
\text { nights }\end{array}$ & $\begin{array}{l}\% \text { of total } \\
\text { trap nights }\end{array}$ & $\begin{array}{l}\text { Mist-net } \\
\text { hours }\end{array}$ & $\begin{array}{l}\% \text { of total } \\
\text { mist-net } \\
\text { hours }\end{array}$ & $\begin{array}{l}\text { Transect } \\
\text { recording } \\
\text { (hours) }\end{array}$ & $\begin{array}{l}\text { Stationary } \\
\text { recording } \\
\text { (hours) }\end{array}$ \\
\hline Wan Hlaing Dam & $850-1,200$ & & 5-7 Feb. & 6 & 9.1 & 162 & 22.6 & 2 & 12 \\
\hline Ziyadam & $850-1,200$ & 54 & 9, 11 Feb. & 12 & 18.2 & 108 & 15.0 & 2 & 12 \\
\hline Wasadam & $850-1,200$ & & 12 Feb. & 0 & 0.0 & 0 & 0.0 & 1 & 0 \\
\hline Mali Raing 1 & $470-690$ & & 16-19 Feb. & 8 & 12.1 & 105 & 14.6 & 1 & 12 \\
\hline Mali Raing 2 & $470-690$ & 0 & 20-24 Feb. & 8 & 12.1 & 88 & 12.3 & 1 & 12 \\
\hline Mali Raing 3 & $470-690$ & & 25-28 Feb. & 8 & 12.1 & 99 & 13.8 & 1 & 12 \\
\hline Shinsanku & $590-1,220$ & & 5-7 Mar. & 8 & 12.1 & 69 & 9.6 & 1 & 4 \\
\hline Gawlai & $590-1,220$ & 81 & 10-11 Mar. & 4 & 6.1 & 0 & 0.0 & 1 & 0 \\
\hline Gathu & $590-1,220$ & & 12-13 Mar. & 6 & 9.1 & 81 & 11.3 & 1 & 12 \\
\hline Tana cave & $590-1,220$ & & 14 Mar. & 0 & 0.0 & 6 & 0.8 & 0 & 0 \\
\hline Htunga & 660 & 30 & 17 Mar. & 6 & 9.1 & 0 & 0.0 & 1 & 0 \\
\hline
\end{tabular}

${ }^{1}$ Number of households within community borders of capture sites.

unpubl. data; Hughes et al., 2010; Hughes et al., 2011; Francis, 2019).

We took 62 non-lethal tissue samples from 27 species for molecular analysis, and 19 voucher specimens of 13 taxonomically ambiguous, small vespertilionid species. We estimated the expected species numbers $S$ based on the spatial effort (capture sites) for the three detection methods, treated separately and combined. We included one unidentified Murina species and one unidentified Myotis species in the analysis. In addition to estimating the expected species numbers for 10 capture sites (Tana cave was excluded from this particular analysis), we extrapolated the expected species numbers for a hypothetical 30 capture sites (for all combined methods and for acoustic/sight sampling) in EstimateS 9.1.o (Colwell, 2013), and for 28 harp-traps and mist-netting capture sites, to examine the difference between observed diversity and theoretically expected diversity. To assess the effort per method, we established a matrix for all detected species with frequency indications per method employed and per sites where they were encountered. The estimator $S$ indicates that our effort would have been maximized with 28 capture sites for harptrapping and 30 capture sites for all other methods.

\section{Results}

We recorded a total of 203 bats of 35 species in six families in the Hkakabo Razi Landscape (Supplementary Table 1), of which two have been described as new species (Murina hkakaboraziensis and Kerivoula furva) and five are new species records for Kachin State, including two that are also new for Myanmar (Kuo et al., 2017; Soisook et al., 2017). The Vespertilionidae with eight genera and 19 species were the most diverse, with $54.3 \%$ of all species recorded (Supplementary Table 1). However, with 64 individuals (31.5\% of captures) their abundance was relatively low. Fruit bats (Pteropodidae) accounted for only $11.4 \%$ of total diversity but $28.6 \%$ of captures. With 38 captures, Cynopterus sphinx was the most commonly captured species. The rank-abundance curves indicate a typical pattern of a few species with many individuals and many species with few individuals (Fig. 2).

The rarefaction curve suggests that if we had tripled our effort and increased the number of capture sites from 11 to a hypothetical 30, we could have expected $48.8 \pm 7.8$ species, an increase of c. one-third. This is based on the three detection methods combined (audio recording, harp-traps and mist-nets; Fig. 3).

Of the 27 species captured in harp-traps and mist-nets, nine were only captured in harp-traps and eight were only captured in mist-nets (Supplementary Table 1). Of the 13 species detected by acoustic/sight surveys, eight were not captured in mist-nets or harp-traps. We recorded six species in Tana cave, the only limestone cave encountered; four of these were captured in mist-nets; two species (Taphozous theobaldi and Hipposideros armiger) were found nowhere else (Supplementary Table 1 ).

Our surveys up to $645 \mathrm{~m}$ (the median elevation) resulted in 22 species and 111 records; at altitudes of $645-1,220 \mathrm{~m}$, we recorded 92 individuals of 31 species (Supplementary Table 1). Of the 203 individual bat records, 130 (64.0\%), representing 25 species, were captured within or near the edge of intact forest. All other species were from secondary forest, settlements or shrub.

\section{Discussion}

Our survey of bats in the Hkakabo Razi Landscape provides a baseline species list for an area nominated as a World Heritage Site. It increases the number of species known from this area from four (Hill, 1962) to 36 , the number known from Myanmar from 100 to 104 species (Bates et al., 2015; Dar et al., 2019; Francis, 2019; Simmons \& Cirranello, 2020), and the number known from Kachin State $(89,041$ $\mathrm{km}^{2}$ ) from 38 to 56 (Fig. 4), which is $14.5 \%$ of South-east 


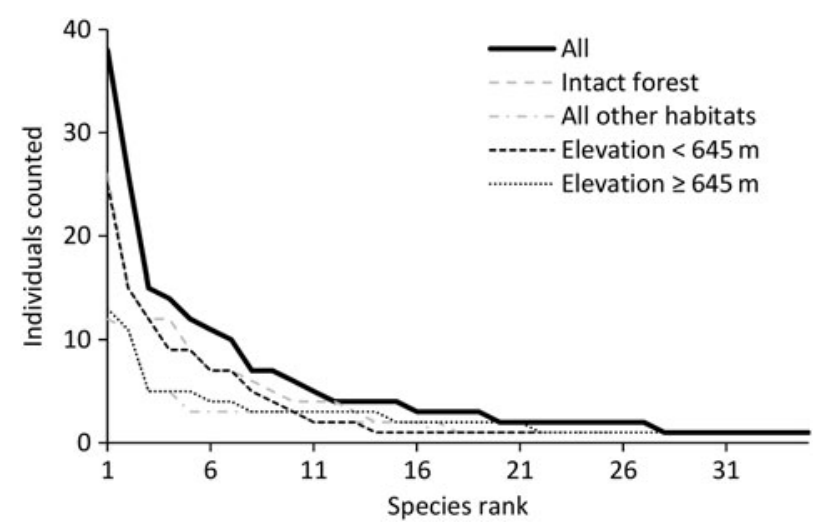

FIG. 2 Species rank-abundance curve based on all capture methods combined, for different habitat types and elevation (median elevation) for bats surveyed in the Hkakabo Razi Landscape in 2016.

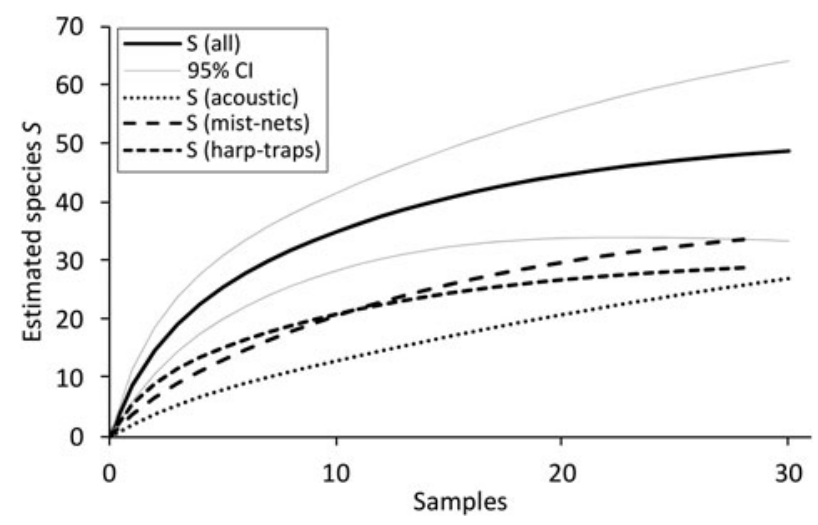

FIG. 3 Species rarefaction curve for all capture methods with $95 \%$ confidence intervals and for 30 hypothetical capture sites, additionally separated for the three capture methods (base: ten capture sites used for all methods and acoustic survey; eight sites for all mist-nets and harp-traps).

Asia's 385 bat species. In a global context, this exceeds the 47 species recorded from North America (Simmons \& Cirranello, 2020), with an area of 24.71 million $\mathrm{km}^{2}$.

However, it is not only the number of species recorded in the Hkakabo Razi Landscape that is remarkable but also the species composition, which indicates that the area is an important refuge for forest-interior specialist bats. We recorded 12 species, belonging to two subfamilies, the Kerivoulinae (Kerivoula, Phoniscus) and Murininae (Murina). Many of these taxa are little-known and have been discovered and described only recently. Two are categorized on the IUCN Red List (IUCN, 2020) as Data Deficient, five as Least Concern, four have yet to be assessed, and one is only identified to genus (Supplementary Table 1). Forest-interior specialist bats are a priority for chiropteran conservation, being most at risk from habitat change. They have strong site fidelity, are less geographically mobile than nomadic generalist bats such as Cynopterus sphinx, and have smaller home ranges that do

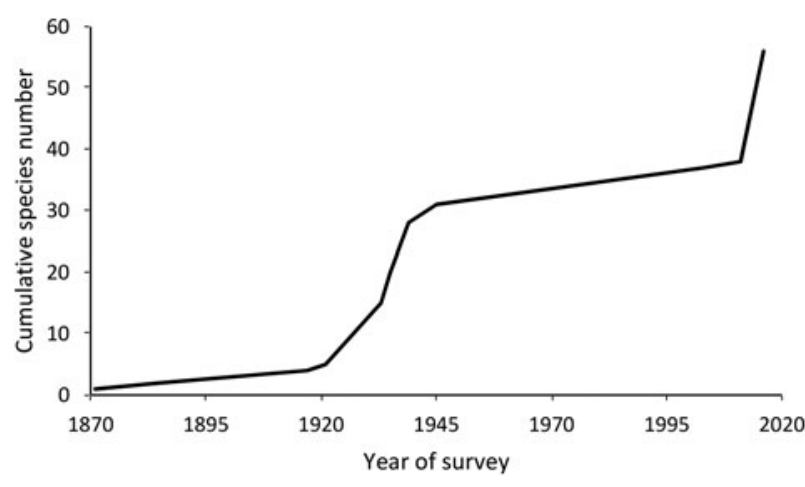

FIG. 4 Cumulative number of bat species recorded from Kachin State, Myanmar (1871-2016), including the number of new species for Kachin from each survey period.

not extend beyond forest boundaries (Struebig et al., 2008; Huang et al., 2019). Compared to cave-roosting bats, they are more susceptible to microclimate and habitat changes and more vulnerable to loss of roosting sites, which include hollows and cavities of standing and fallen trees (Struebig et al., 2008). Furthermore, they have eco-morphological adaptations, which constrain their ecological flexibility (Furey et al., 2010). These include specialized wing morphology (low wing loading, low aspect ratios), which restricts them to hunting in environments with dense vegetation (Schnitzler \& Kalko, 2001), and specialized acoustic characteristics (short duration, low intensity but very high frequency calls), which allow them to glean their arthropod prey in narrow spaces but is ill-suited for prey detection in more open habitats (Kingston et al., 2003).

Baseline data for the Hkakabo Razi Landscape contribute to our understanding of the ecology, diversity, composition, assemblages, and the natural spatio-temporal changes of the bat fauna in an intact eastern Himalayan forest. This will help to devise effective conservation strategies. With further, more temporally and spatially widespread research within Hkakabo Razi, these data will complement those obtained elsewhere in the Indo-Chinese subregion and from South-east Asia's Sundaic lowland forest bats, such as from Krau Wildlife Reserve in peninsular Malaysia. Krau is considered home to 'the highest diversity of bats recorded anywhere in the Old World tropics' (Kingston et al., 2009, p. 11), with $>70$ bat species, including 14 species of Kerivoulinae and Murininae, recorded during 1980-2008 (Struebig et al., 2008).

Apart from Krau, the Hkakabo Razi forests have one of the highest recorded diversities of forest-interior specialist bat species in the Murininae and Kerivoulinae. In Bukit Barisan Selatan National Park, one of the last refuges of intact forest in Sumatra, of a total of 60 bat species, 11 were forest-interior specialists in these subfamilies (Huang et al., 2014). In the disturbed forests of Kim Hy Nature Reserve, Viet Nam, which includes extensive limestone 
karst, 42 species were recorded, but the diversity of forestinterior bats is considerably lower, with five Murininae and two Kerivoulinae (Furey et al., 2010). In the watershed protection forest in the south-eastern Truong Son (Annamite Mountains), 20 species were recorded, including six forestinterior bats, one Kerivoulinae and five Murininae (Son et al., 2016). Although other areas in Viet Nam have a bat diversity comparable to that of the Hkakabo Razi Landscape (Put Mat with 39 species, Cuc Phuong with 38 species and Phong Nha with 32 species), the number of forest specialists is lower. However, most of the surveys there were undertaken prior to the use of harp-traps (Hendrichsen et al., 2001). Our findings from Hkakabo Razi reinforce the view that large forest tracts should be conservation priorities in landscape-level planning because they support rare, forest specialist species (Struebig et al., 2010).

Although our survey was short and geographically restricted, it indicates that the Hkakabo Razi Landscape has a highly diverse bat fauna and is a conservation priority for bats in South-east Asia. As one of the last remaining extensive tracts of mainly intact forest in Asia, it fully deserves the protection that could be provided through a listing as a World Heritage Site.

Acknowledgements We thank the Director General of the Forest Department in the Ministry of Nature Conservation and Environmental Protection, U Nyi Nyi Kyaw and Deputy Director U Naing Zaw Htun for permission to study; UNESCO for financial support (grants 4500291033, 7833010728); Koen Myers for discussion on World Heritage; the staff of Hkakabo Razi National Park, particularly U San Naing Dee for logistical support; U Aung Kyaw for organizing the trip in 2016; and U San Lwin Oo, Dee Shin, Htin, Hdoa Dee and numerous porters, cooks and assistants for their help during the expeditions.

Author contributions Study design: SCR, PJJB; fieldwork: PS, SSLO, AP; data analysis: MSR, AD, PS, SSLO, AP; writing: PJJB; revisions: all authors.

\section{Conflicts of interest None.}

Ethical standards This work abided by the Oryx guidelines on ethical standards. The Nature and Wildlife Conservation Division of the Forestry Department (NWCD) endorsed the study and granted permission to capture bats and access the protected areas under a contract with UNESCO (Phase II 504MYA4001). All voucher specimens were taken in accordance with national Myanmar law and the animal protection laws of the EU. All procedures were approved by the Nagoya Protocol process, represented by MoNREC NR-2/2-2017.

\section{References}

Bates, P.J.J., Tin Nwe, Pearch, M.J., Swe, K.M., Bu, S.S.H. \& Tun, T. (2000) A review of bat research in Myanmar (Burma) and results of a recent survey. Acta Chiropterologica, 2, 53-82.

Bates, P.J.J., Struebig, M.J., Rossiter, S.J., Kingston, T., Oo, S.S.L. \& My , K.M. (2004) A new species of Kerivoula (Chiroptera: Vespertilionidae) from Myanmar (Burma). Acta Chiropterologica, 6, 219-227.
Bates, P.J.J., Tun, O., Aung, M.M., Lu, A., Lum, M.R. \& Sein, M.M. (2015) A review of Hipposideros lankadiva Kelaart, 1850 (Chiroptera: Hipposideridae) with a description of a new subspecies from Myanmar. Tropical Natural History, 15, 191-204.

Bhagwat, T., Hess, A., Horning, N., Khaing, T., Thein, Z.M., Aung, K.M., AUng, K.H. et al. (2017) Losing a jewel—rapid declines in Myanmar's intact forests from 2002-2014. PLOS ONE, 12, e0176364.

Cardillo, M., Mace, G.M., Gittleman, J.L. \& Purvis, A. (2006) Latent extinction risk and the future battlegrounds of mammal conservation. Proceedings of the National Academy of Sciences of the United States of America, 103, 4157-4161.

Colwell, R.K. (2013) EstimateS: Statistical Estimation of Species Richness and Shared Species from Samples. Version 9.1.o. User's guide and application. Museum of Natural History, Boulder, USA viceroy.eeb.uconn.edu/estimates [accessed 16 December 2020].

Curtis, P.G., Slay, C.M., Harris, N.L., Tyukavina, A. \& Hansen, M.C. (2018) Classifying drivers of global forest loss. Science, 361, 1108-1111.

Dar, T.H., Kamalakannan, M., Venkatraman, C. \& Chandra, K. (2019) New record of Hipposideros speoris (Chiroptera: Hipposideridae) from Myanmar hidden in the National Zoological Collections of the Zoological Survey of India. Mammalia, $83,515-517$.

Estoque, R.C., Oовa, M., Avitabile, V., Hijioka, Y., DasGupta, R., Togawa, T. \& Murayama, Y. (2019) The future of Southeast Asia's forests. Nature Communications, 10, 1829.

Francis, C. (2019) Field Guide to the Mammals of South-East Asia. Bloomsbury Publishing, London, UK.

Frick, W.F., Kingston, T. \& Flanders, J. (2019) A review of the major threats and challenges to global bat conservation. Annals of the New York Academy of Sciences, 1469, 5-25.

Furey, N.M., Mackie, I.J. \& RaCeY, P.A. (2010) Bat diversity in Vietnamese limestone karst areas and the implications of forest degradation. Biodiversity and Conservation, 19, 1821-1838.

Hendrichsen, D.K., Walston, J.L., Bates, P.J.J. \& Hayes, B. (2001) Recent records of bats (Mammalia: Chiroptera) from Vietnam with six species new to the country. Myotis, 39, 35-122.

Hill, J. (1962) Notes on some insectivores and bats from Upper Burma. Journal of Zoology, 139, 119-137.

Huang, J.C.-C., JaZdzyk, E.L., Nusalawo, M., Maryanto, I., Maharadatunkamsi, Wiantoro, S. \& Kingston, T. (2014) A recent bat survey reveals Bukit Barisan Selatan Landscape as a Chiropteran diversity hotspot in Sumatra. Acta Chiropterologica, $16,413-449$.

Huang, J.C.C., Rustiati, E.L., Nusalawo, M. \& Kingston, T. (2019) Echolocation and roosting ecology determine sensitivity of forest-dependent bats to coffee agriculture. Biotropica, $51,757-768$.

Hughes, A.C. (2017) Understanding the drivers of Southeast Asian biodiversity loss. Ecosphere, 8, eo1624.

Hughes, A.C., Satasook, C., Bates, P.J.J., Soisook, P., SRitongchuay, T., Jones, G. \& Bumrungsri, S. (2010) Echolocation call analysis and presence-only modelling as conservation monitoring tools for Rhinolophoid bats in Thailand. Acta Chiropterologica, 12, 311-327.

Hughes, A.C., Satasook, C., Bates, P.J.J., Soisook, P., Sritongchuay, T., Jones, G. \& Bumrungsri, S. (2011) Using echolocation calls to identify Thai bat species: Vespertilionidae, Emballonuridae, Nycteridae and Megadermatidae.

Acta Chiropterologica, 13, 447-455.

IUCN (2020) The IUCN Red List of Threatened Species. Version 2020-1. IUCN, Gland, Switzerland. iucnredlist.org [accessed 19 November 2020]. 
Keenan, R.J., Reams, G.A., Achard, F., Freitas, J.V., Grainger, A. \& LiNDQUist, E. (2015) Dynamics of global forest area: results from the FAO Global Forest Resources Assessment 2015. Forest Ecology and Management, 352, 9-20.

Kingston, T., Liat, L.B. \& Akва , Z. (2009) Bats of Krau Wildlife Reserve. Penerbit Universiti Kebangsaan Malaysia, Bangi, Malaysia.

Kingston, T. (2010) Research priorities for bat conservation in Southeast Asia: a consensus approach. Biodiversity and Conservation, 19, 471-484.

Kingston, T. (2013) Response of bat diversity to forest disturbance in Southeast Asia - insights from long-term research in Malaysia. In Bat Evolution, Ecology, and Conservation (eds R.A. Adams \& S.C. Pedersen), pp. 169-185. Springer Science Press, New York, USA.

Kingston, T., Francis, C.M., Akbar, Z. \& Kunz, T.H. (2003) Species richness in an insectivorous bat assemblage from Malaysia. Journal of Tropical Ecology, 19, 67-79.

Kuo, H.-C., Soisook, P., Ho, Y.-Y., Csorba, G., Wang, C.-N. \& Rossiter, S.J. (2017) A taxonomic revision of the Kerivoula hardwickii complex (Chiroptera: Vespertilionidae) with the description of a new species. Acta Chiropterologica, 19, 19-39.

Myers, N., Mittermeier, R.A., Mittermeier, C.G., Da Fonseca, G.A. \& KENT, J. (2000) Biodiversity hotspots for conservation priorities. Nature, 403, 853-858.

Rao, M., Saw, H., Platt, S.G., Tizard, R., Poole, C., Than, M. \& Watson, J.E. (2013) Biodiversity conservation in a changing climate: a review of threats and implications for conservation planning in Myanmar. Ambio, 42, 789-804.

Renner, S.C., Rappole, J.H., Leimgruber, P., Kelly, D.S., Shwe, N.M., Aung, T. \& AUng, M. (2007) Land cover in the Northern Forest Complex of Myanmar: new insights for conservation. Oryx, 41, 27-37.

Renner, S.C. \& Rappole, J.H. (2011) Avifauna of the Eastern Himalayas and Southeastern Sub-Himalayan Mountains - Center of Endemism or Many Species in Marginal Habitats? American Ornithologists' Union, Washington, DC, USA.

Renner, S.C., Rappole, J.H., Milensky, C.M., Aung, M., Shwe, N.M. \& AUNG, T. (2015) Avifauna of the southeastern Himalayan
Mountains and neighboring Myanmar hill country. Bonn Zoological Bulletin-Supplementum, 62, 1-75.

Schnitzler, H.-U. \& Kalko, E.K.V.K. (2001) Echolocation by insect-eating bats. BioScience, 51, 557-569.

Simmons, N.B. \& Cirranello, A.L. (2020) Bat Species of the World: A Taxonomic and Geographic Database. American Museum of Natural History, New York, USA.

Sodhi, N.S., Koh, L.P., Brook, B.W. \& NG, P.K.L. (2004) Southeast Asian biodiversity: an impending disaster. Trends in Ecology \& Evolution, 19, 654-66o.

Soisook, P., Thaw, W.N., Kyaw, M., Lin Oo, S.S., Pimsai, A., Suarez-Rubio, M. \& Renner, S.C. (2017) A new species of Murina (Chiroptera: Vespertilionidae) from sub-Himalayan forests of northern Myanmar. Zootaxa, 4320, 159.

Son, N.T., O'Shea, T.J., Gore, J.A., Csorba, G., Tu, V.T., Oshida, T., Endo, H. \& Мотокоwa, M. (2016) Bats (Mammalia: Chiroptera) of the southeastern Truong Son Mountains, Quang Ngai Province, Vietnam. Journal of Threatened Taxa, 8, 8953.

Struebig, M.J., Kingston, T., Zubaid, A., Mohd-Adnan, A. \& Rossiter, S.J. (2008) Conservation value of forest fragments to Palaeotropical bats. Biological Conservation, 141, 2112-2126.

Struebig, M.J., Rossiter, S.J., Bates, P.J.J., Kingston, T., Oo, S.S.L., Nwe, A.A., Aung, M.M. et al. (2005) Results of a recent bat survey in Upper Myanmar including new records from the Kachin forests. Acta Chiropterologica, 7, 147-163.

Struebig, M.J., Christy, L., Pio, D. \& Meijaard, E. (2010) Bats of Borneo: diversity, distributions and representation in protected areas. Biodiversity and Conservation, 19, 449-469.

Suarez-Rubio, M., Connette, G., Kyaw, M., Meyers, K., Thaw W.N. \& RenneR, S.C. (2020) Hkakabo Razi Landscape as one of the last exemplar of large contiguous forests. Scientific Reports, 10, 14005 .

W ORLD BANK (2005) Vietnam Environment Monitor 2005: Biodiversity (English). WorldBank, Washington, DC, USA.

World Heritage Center (2014) Hkakabo Razi Landscape (Tentative Lists Ref.: 5871). World Heritage Center, Paris, France. whc.unesco.org/en/tentativelists/5871 [accessed 4 March 2020]. 